\title{
Impacts of Leadership Empowerment on Psychology and Work Outcomes of Employees at Financial Institutions in Ho Chi Minh City
}

\author{
Van Dung Ha ${ }^{*}$, Hoang Tien Nguyen ${ }^{2}$ \\ 1.Banking University Ho Chi Minh City, Vietnam. \\ 2.The Saigon International University, Vietnam.
}

*Corresponding Author: Van Dung Ha

\begin{abstract}
This study focuses on determining the impacts of Leadership Empowerment (LP) on the Psychological Empowerment (PE) and Work Outcomes (WO) of employees at financial institutions in Ho Chi Minh City. Based on the investigation forms of 361 employees working at financial institutions in Ho Chi Minh City, statistical methods, reliability assessment of Cronbach's Alpha scale, exploratory factor analysis (EFA), confirmatory factor analysis (CFA) and structural equation model (SEM) are used for the analysis. The results show that the LP positively affects the PE and WO of employees, and the $\mathrm{PE}$ positively affects the WO of employees.
\end{abstract}

Keywords: Leadership, Empowerment, Psychology, Finance, Outcomes.

\section{Introduction}

Leadership Empowerment (LP) is becoming increasingly important in every organization where the leaders cannot carry out most of their management tasks on their own. In addition, organizations performing much LP to their employees will create conditions for the employees to develop their confidence, autonomy, understand their role in the organization and actively participate in making important decisions of the organization with their leader [1].

LP helps leaders reduce unnecessary decisionmaking, gradually transfer decision-making power to subordinates, giving employees more autonomy in their work. Along with that, the implementation of LP helps employees have a better mentality at work, employees will better understand the tasks they are undertaking, be confident in their working skills, raise their working awareness, and above all, be self-determining in all workrelated matters [2].

Therefore, in an invisible way, LP has positive impacts on psychological empowerment, which has been proved by, not only that, leadership and psychological empowerment also promote the employees' work outcomes .
Above all, in the financial institutions, LP will help employees be more proactive in conducting transactions with customers more quickly, increasing competition with other organizations. In particular, with the need for faster problem solving from the customers, LP is considered as a stepping stone for increasing service quality [3-4-5]. Therefore, the study is to identify and measure the degree of impact of LP on Psychological Empowerment and Employee Performance at financial institutions in Ho Chi Minh City; On that basis, the study proposes administrative implications to improve the employees' work outcomes of at financial institutions in $\mathrm{Ho}$ Chi Minh City.

\section{Theoretical Basis}

\section{Leadership Empowerment (LP)}

Over the years, LP has become as a different form of leadership style [6]. LP is a combination of four issues: promoting participation in decision-making, enhancing the meaning of work, and improve the autonomy at work and confidence [1]. LP is characterized by creativity, positive impact and inspiring employees to monitor leaders' behaviors [7-8]. 
It addresses the positive direction for leaders to transfer their power to subordinates [2]. Moreover, LP encourages the employee involvement by providing greater autonomy[8].

\section{Psychological Empowerment (PE)}

Concerning PE, the main concern is the employees' psychological state, which is under psychological experience of power in their work [2-9]. PE as a structure related to work motivation expressed through four issues: Deep understanding of duties, selfdetermination, confidence in working abilities and sense at work [2].

\section{Work Outcomes (WO)}

Campbell [10] defined work outcomes as the value of all employee activities that contribute both directly and indirectly to the accomplishment of the organization's goals and subsequently with colleagues as actions related to individual goals [10]. A more recent definition of Motowidlo [11] stated that work outcomes are the total expected value that individuals perform on the work they are assigned.

There are two approaches to measuring the work outcomes of employees; one is an objective approach that focuses on the actual results of the work that an employee does and the other is a subjective approach that focuses on the performance of the employee's work duties instead of the results of work [12].

The relationship between Leadership Empowerment (LP) and Psychological Empowerment (PE) LP is the transfer of a decision-making to a subordinate, and the $\mathrm{PE}$ shows the subordinate's reaction to LP [6]. The problem of leaders who want to empower employees will not succeed if employees do not experience the power of that empowerment issue in terms of psychology [13]. Previous studies found positive links between the LP and PE [5]. LP has both direct and indirect (through self-leadership) impacts on PE [6].

In a study of public institutions, the relationship between LP and PE actually exists [14]. The act that leaders express empowerment behaviors by supporting independent actions, creating leadership and developping opportunities for employees will empower the employees [3].
The positive combination of leadership and $\mathrm{PE}$ has been demonstrated in various studies [1-15-16].

\section{Based on the Above, the Study Proposes the Following Hypothesis}

\section{Hypothesis $\mathrm{H} 1$}

Leadership empowerment has a positive impact on psychological empowerment. The relationship between Leadership Empowerment (LP) and Work Outcomes (WO) Many empirical studies have demonstrated the direct or indirect relationship of LP towards the WO of employees [17-16]. Humborstad et al. [17] Demonstrated that LP has positive impacts on the WO of employees based on the level of empowerment shown by the leaders.

The study of Raub and Robert [13] shown that LP directly and positively affecs WO through PE. In a similar study of urban employees in South Africa, LP was found to be closely related to employees' work effort and WO [18]. Sharing the same view, Chow [19] also pointed out that LP helps enhance the creativity among subordinates and can improve WO.

\section{Based on the Above, the Study Proposes the Following Hypothesis}

\section{Hypothesis $\mathrm{H} 2$}

Leadership empowerment has positive impacts on work outcomes.

The relationship between Psychological Empowerment (PE) and Work Outcomes (WO) Many previous empirical studies have demonstrated a strong relationship between $\mathrm{PE}$ and WO [2-20]. WO of employees are deeply affected by their level of PE [20-21].

Seibert et al [22]. Have demonstrated that PE is the source of enhancing the WO of employees. It should be noted that $\mathrm{PE}$ employees are more likely to acquire knowledge [23] and this will enhance their WO. Çetin and Askun [24], PE creates selfmotivation and internal motivation among employees and has a positive impact on WO.

\section{Based on the Above, the Study Proposes the Following Hypothesis}

\section{Hypothesis $\mathrm{H} 3$}

Psychological empowerment has a positive impact on work outcomes. 


\section{Research Methodology}

\section{The Research Methods are Used as Follows}

- Qualitative method: It is conducted in a sequence based on the literature review and overview of the previous relevant studies to propose the preliminary research hypotheses and models. Then, the author conducted a group discussion with 10 experts to supplement and adjust the observed variables of the factors of Leadership Empowerment, Psychological empowerment and Work outcomes in the preliminary research model in conformity with the context of research at the financial institutions in Ho Chi Minh City. The research results will be formed as the basis for developing a likert scale (from 1 "strongly disagree" to 5 "strongly agree") and questionnaire to collect the data for quantitative research.

- Quantitative method: the research samples in the quantitative research were conducted by a convenient sampling method with a sample size of 361 employees working at the financial institutions in Ho Chi Minh City.

The data was collected in the following specific way: the author contacted and asked for permission from financial institutions in Ho Chi Minh City, then proceeded to directly send survey questionnaires to employees for interview and get immediate results. According to Hoang and Chu [25], Nguyen and Nguyen [26], the collected data is processed by SPSS 20 and AMOS 20 software, including the statistics, assessments of the reliability of the scales of measurement with Cronbach's alpha test, Exploratory Factor Analysis (EFA) with Bartlett and KMO tests, Confirmatory Factor Analysis (CFA) and Linear Structural Equation Model (SEM) to analyze the impacts of leadership empowerment on the psychology and work outcomes of employees at financial institutions in ho chi minh city.

Table 1: The scales belong to factors of the research model

\begin{tabular}{|c|c|c|c|c|}
\hline \\
\hline S.No. & Factor & Encryption & Scale & Source \\
\hline 1 & \multirow{6}{*}{$\begin{array}{l}\text { Leadership } \\
\text { Empowerment }\end{array}$} & LP1 & $\begin{array}{l}\text { My superiors believe in my working ability } \\
\text { even when I make a mistake }\end{array}$ & \multirow{6}{*}{$\begin{array}{l}\text { Ahearne et } \\
\text { al. [1] }\end{array}$} \\
\hline 2 & & LP2 & $\begin{array}{l}\text { My superiors help me see the importance of } \\
\text { the work that I'm doing to the overall } \\
\text { effectiveness of the organization }\end{array}$ & \\
\hline 3 & & LP3 & $\begin{array}{l}\text { My superiors believe that I can handle every } \\
\text { assigned works }\end{array}$ & \\
\hline 4 & & $\mathrm{LP} 4$ & $\begin{array}{c}\text { My superiors strongly believe in my working } \\
\text { ability }\end{array}$ & \\
\hline 5 & & LP5 & $\begin{array}{c}\text { My superiors make it easier for me to make } \\
\text { a work-related decision }\end{array}$ & \\
\hline 6 & & LP6 & $\begin{array}{l}\text { My superiors allow me to make important } \\
\text { decisions myself }\end{array}$ & \\
\hline 7 & \multirow{4}{*}{$\begin{array}{l}\text { Psychological } \\
\text { empowerment }\end{array}$} & PE1 & My works is important to the organization & \multirow{4}{*}{$\begin{array}{l}\text { Spreitzer's } \\
{[2]}\end{array}$} \\
\hline 8 & & PE2 & $\begin{array}{l}\text { I have mastered the skills needed for my } \\
\text { work }\end{array}$ & \\
\hline 9 & & PE3 & $\begin{array}{l}\text { I have a significant autonomy in } \\
\text { determining how my work is done }\end{array}$ & \\
\hline 10 & & $\mathrm{PE} 4$ & $\begin{array}{l}\text { My work greatly affects the overall work of } \\
\text { the organization I work at }\end{array}$ & \\
\hline 11 & \multirow{4}{*}{ Work outcomes } & WO1 & My work outcomes exceeded expectations & \multirow{4}{*}{$\begin{array}{l}\text { Yilmaz's } \\
{[12]}\end{array}$} \\
\hline 12 & & WO2 & My work outcomes exceeded my goals & \\
\hline 13 & & WO3 & I completed the assigned task on time & \\
\hline 14 & & WO4 & $\begin{array}{l}\text { I respond quickly to problems that arise at } \\
\text { work }\end{array}$ & \\
\hline
\end{tabular}

Source: Synthesized by the author

According to Hoang and Chu [25], the sample size must be at least four or five times the number of observed variables. Thus, in this study, the author uses a minimum number of research votes corresponding to 14 observed variables: 5 x $14=70$ observations. However, to ensure the persuasion and quality of the model results, the author conducted a survey of 400 votes, including 361 valid questionnaires with all the information on the questionnaire. 
Table 2: Descriptive statistics results

\begin{tabular}{|c|l|c|c|}
\hline \multirow{3}{*}{ Variable } & \multicolumn{1}{|c|}{ Content } & Frequency (n) & \\
& & & Percent (\%) \\
\hline \multirow{3}{*}{ Gender } & Male & 194 & 53.7 \\
\cline { 2 - 4 } & Female & 167 & 46.3 \\
\hline \multirow{3}{*}{ Education } & Intermediate and college & 25 & 6.9 \\
\cline { 2 - 4 } & University & 224 & 32.0 \\
\cline { 2 - 4 } & Postgraduate & 112 & 31.0 \\
\hline \multirow{3}{*}{ Age } & $<30$ & 62 & 38.2 \\
\cline { 2 - 4 } & $30-40$ & 137 & 33.0 \\
\cline { 2 - 4 } & $41-50$ & 119 & 11.9 \\
\cline { 2 - 4 } Income & $>50$ & 43 & 16.1 \\
\cline { 2 - 4 } & $<5$ million VND/month & 58 & 61.5 \\
\cline { 2 - 4 } & $5-10$ million VND/month & 222 & 22.4 \\
\hline
\end{tabular}

Source: SPSS Analysis Results.

Among 361 employees, there are 167 female employees, accounting for $46.3 \%$ and 194 male employees, accounting for $53.7 \%$, this result shows that the difference between male and female employees is not too much. Education level is mainly university accounting for $62.0 \%$; Intermediate and colleges accounting for only $6.9 \%$ because most financial institutions employ only university and postgraduate staff. Age is mainly from 30 to 50 years old, accounting for $71.0 \%$. Income from VND 5 to 10 million/ month accounting for the highest proportion with $61.5 \%$; because this is the average income of employees working at financial institutions in Ho Chi Minh City.

\section{Results}

Cronbach's Alpha's results show that, Cronbach's Alpha coefficient reaches the maximum value of 0.935 belongs to the Leadership Empowerment factor; the lowest Cronbach's Alpha coefficient is 0.799, which belongs to the Psychological Empowerment factor. All Cronbach's Alpha coefficients of the factors are relatively high from 0.7 upwards. The correlation coefficient of the total variables is greater than 0.3 , showing that the variables are closely correlated, ensuring all variables (14 variables of 3 factor groups) meet the requirements of Structural Equation Model SEM analysis.

Table 3: Cronbach's alpha analysis results

\begin{tabular}{|c|c|c|}
\hline Factor & Cronbach's Alpha & Variable \\
\hline Leadership Empowerment & 0.935 & 6 \\
\hline Psychological Empowerment & 0.799 & 4 \\
\hline Work Outcomes & 0.855 & 4 \\
\hline
\end{tabular}

Source: SPSS Analysis Results.

Next, the author analyzes EFA to explore the structure of a scale of factors: LP (Leadership Empowerment), PE (Psychological
Empowerment), WO (Work Outcomes). Conducting EFA analysis for a total of 14 variables of the scales belonging to factors, the study obtained the results presented in Table 4.

Table 4: Efa analysis results

\begin{tabular}{|c|c|c|}
\hline \multicolumn{2}{|c|}{ KMO } & $\mathbf{0 . 7 1 8}$ \\
\hline \multirow{3}{*}{ Bartlett's test of sphericity } & Approx. Chi-Square & $5,936.706$ \\
\cline { 2 - 3 } & $\mathrm{df}$ & 91 \\
\cline { 2 - 3 } & Sig. & 0.000 \\
\hline
\end{tabular}

Source: SPSS Analysis Results.

The EFA's result show that, $\mathrm{KMO}=0.718$, the Approx. Chi-Square is 5,936.706 with significance level of 0.00 . This confirms the KMO value ensuring the appropriateness of EFA and the significance level of the data put into performing factor analysis. 
Table 5: Rotated component matrix

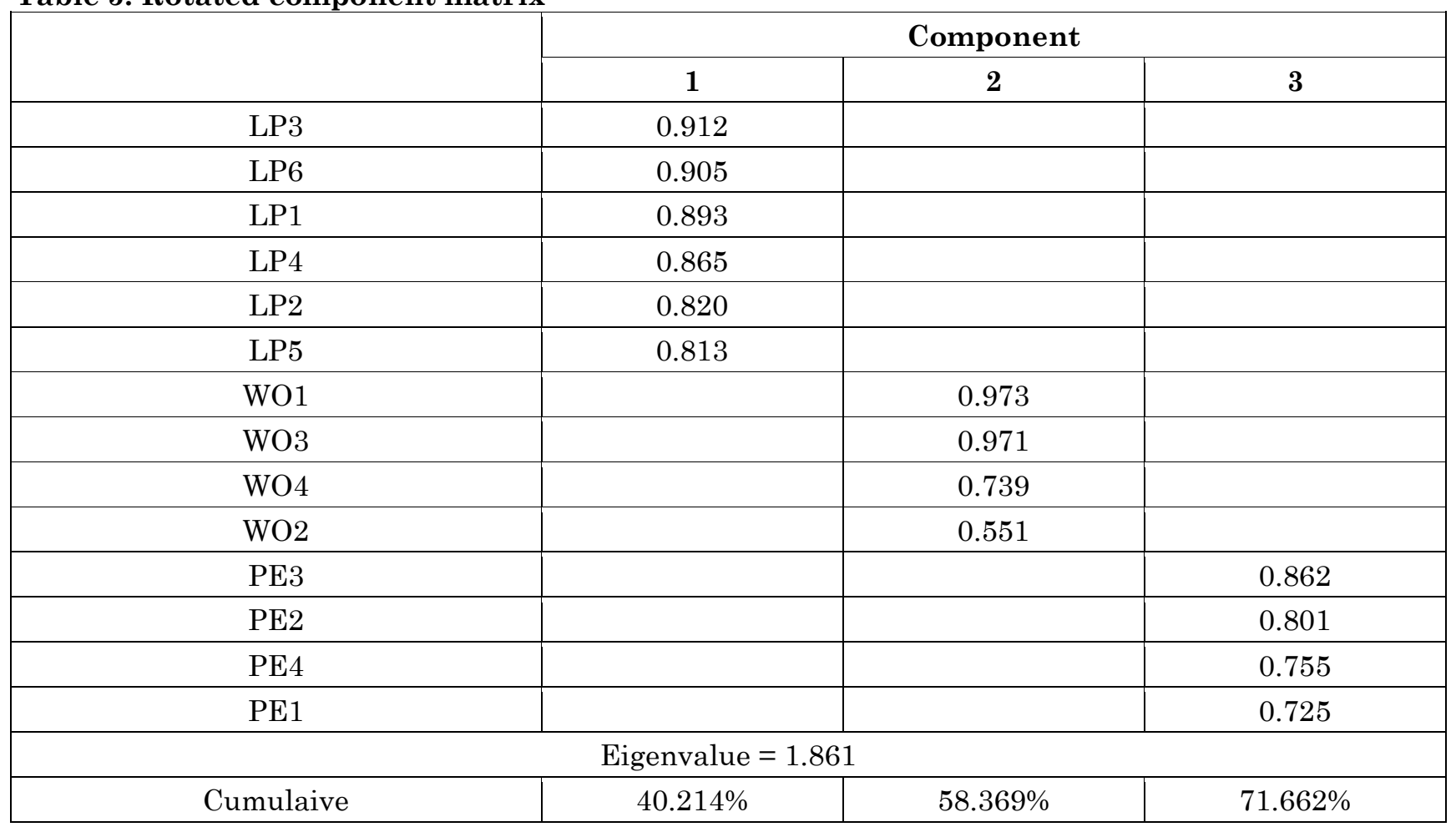

LP (Leadership Empowerment), PE (Psychological Empowerment), WO (Work Outcomes)

Source: SPSS Analysis Results.

In addition, analysis of extracted variance shows that $71.662 \%$ of data variability explained by three factors. The scales are drawn and accepted, the stopping point when extracting factors at the third factor with a specific value of $1.861>1$ (the variables are arranged into three factor groups). The results of factor rotation show that all factors are satisfactory (factor load factor values are greater than 0.5) and arranged in three separate groups of factors, these are groups of factors LP (Leadership Empowerment), PE (Psychological Empowerment), WO (Work Outcomes). Next, perform Confirmatory Factor Analysis CFA using AMOS software with the purpose of checking the influence of factors together.

Table 6: CFA analysis results according to standardized coefficients

\begin{tabular}{|c|c|c|}
\hline S. No. & Content & Value \\
\hline 1 & Chi-square/df & 2.824 \\
\hline 2 & P-value của Chi-square & 0.000 \\
\hline 3 & GFI & 0.930 \\
\hline 4 & TLI & 0.971 \\
\hline 5 & CFI & 0.978 \\
\hline 6 & RMSEA & 0.071 \\
\hline
\end{tabular}

Source: AMOS Analysis Results.

The results show that the value of Chisquare/df $=2.824$ is less than $3, \mathrm{GFI}=0.930$ is greater than 0.9 , TLI $=0.971$ is greater than 0.95 , CFI $=0.978$ is greater than 0.95 and RMSEA $=0.071$ is less than 0.1 ; Therefore, it can be said that the model is suitable for market data. At the same time, the standardized weights are greater than 0.5. That is statistically significant, so the concepts achieve convergent value. Thus, with CFA analysis results, the main factors are included in the analysis, which are: LP (Leadership Empowerment), PE (Psychological Empowerment), WO (Work Outcomes).

Table 7: Composite reliability and Variance extracted

\begin{tabular}{|c|c|c|c|}
\hline S.No. & Factor & Composite reliability & Variance extracted \\
\hline 1 & Leadership Empowerment & 0.801 & 0.703 \\
\hline 2 & Psychological Empowerment & 0.714 & 0.701 \\
\hline 3 & Work Outcomes & 0.823 & 0.733 \\
\hline
\end{tabular}

Source: AMOS Analysis Results. 


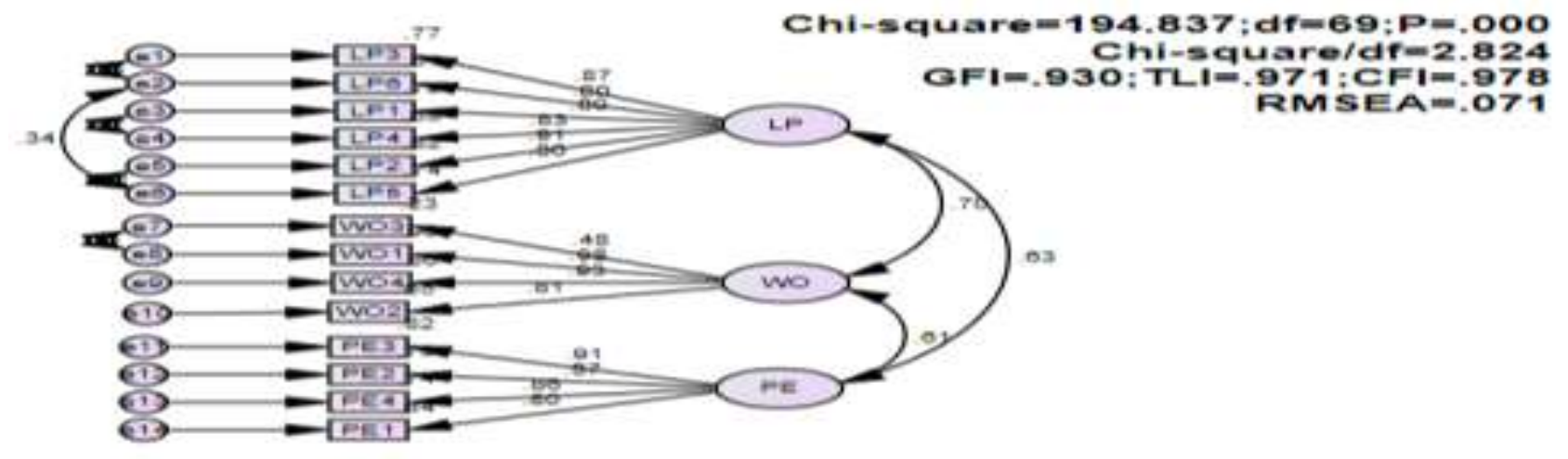

Figure 1: CFA analysis results according to standardized coefficients LP (Leadership Empowerment), PE (Psychological Empowerment), WO (Work Outcomes)

Source: Authors' calculation results.

Along with that, the research paper calculates the total reliability value and the total variance extracted to assess the reliability of the scales. The results showed that the combined reliability values and total variance extracted of all factors were greater than 0.5. This shows the factors that ensure reliability when included in the analysis. And the Pvalue of the correlation coefficients in each pair is less than 0.05 (i.e. less than 5\%), so the correlation coefficient of each pair of concepts is different from 1 at the significant level of $5 \%$. Therefore, the concepts gain discriminatory value. To perform the analysis of the Structural Equation Model SEM, showing the impacts of leadership empowerment on the psychology and work outcomes of employees at financial institutions in Ho Chi Minh City, the author transforms model obtained from CFA analysis results to Structural Equation Model SEM.

Table 8: SEM analysis results according to standardized coefficients.

\begin{tabular}{|c|c|c|}
\hline S.No. & Content & Value \\
\hline 1 & Chi-square/df & 2.824 \\
\hline 2 & P-value của Chi-square & 0.000 \\
\hline 3 & GFI & 0.930 \\
\hline 4 & TLI & 0.971 \\
\hline 5 & CFI & 0.978 \\
\hline 6 & RMSEA & 0.071 \\
\hline
\end{tabular}

Source: AMOS Analysis Results

Inheriting from the CFA analysis results can be easily seen, the results of the Structural Equation Model SEM are consistent with market data. This is reflected in such indicators as: Chi-square/df value $=2.824$ less than 3 , GFI $=0.930$ greater than 0.9 , TLI $=$ 0.971 greater than $0.95, \mathrm{CFI}=0.978$ greater than 0.95 and RMSEA $=0.071$ is less than 0.1 .

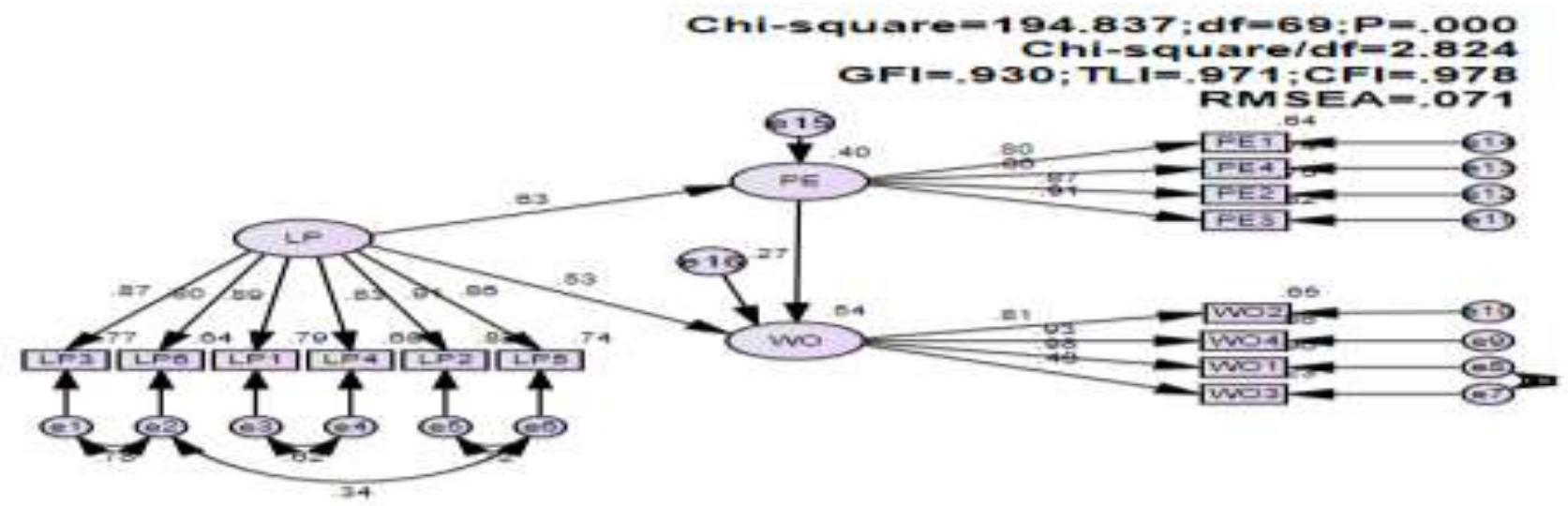

Figure 2: Results of the structural model analysis show the impacts of leadership empowerment on the psychology and work outcomes of employees at financial institutions in Ho Chi Minh City LP (Leadership Empowerment), PE (Psychological Empowerment), WO (Work Outcomes)

Source: AMOS Analysis Results 
Table 9: Results of the structural model analysis

\begin{tabular}{|c|c|c|c|c|c|c|}
\hline \multicolumn{2}{|c|}{ Relationship } & Estimate & S.E. & C.R. & P-Value \\
\hline PE & $<---$ & LP & 0.655 & 0.053 & 12.267 & $* * *$ \\
\hline WO & $<---$ & PE & 0.097 & 0.022 & 4.477 & $* * *$ \\
\hline WO & $<---$ & LP & 0.199 & 0.029 & 6.859 & $* * *$ \\
\hline
\end{tabular}

LP (Leadership Empowerment), PE (Psychological Empowerment), WO (Work Outcomes), ***: 0,000 (0,0\%)

Source: AMOS Analysis Results.

At the same time, based on the analysis results, the P-Value of the influence relationships between the factors, we see, the P-Value is less than 5\%. Therefore, the relationships among the factors LP (Leadership Empowerment), PE (Psychological Empowerment), WO (Work Outcomes) are statistically significant in Structural Equation Model SEM.

Table 10: Results of the structural model analysis according to standardized coefficients

\begin{tabular}{|c|c|c|c|c|}
\hline \multicolumn{2}{|c|}{ Relationship } & Standardized estimate & $\begin{array}{c}\text { Standardized estimate according to the } \\
\text { diagram }\end{array}$ \\
\hline PE & $<---$ & LP & 0.630 & 0.63 \\
\hline WO & $<--$ & PE & 0.271 & 0.27 \\
\hline WO & $<---$ & LP & 0.534 & 0.53 \\
\hline
\end{tabular}

LP (Leadership Empowerment), PE (Psychological Empowerment), WO (Work Outcomes)

Source: AMOS Analysis Results

When considering the regression coefficient values among factors, it shows that the regression coefficient values are all greater than zero, which means that there is a positive impact between the factors as follows:

The Leadership Empowerment factor has a positive impact on Psychological Empowerment and Work Outcomes of employees with regression coefficients of 0.63 and 0.53. This means that, once the Leadership Empowerment factor is better, the employees' Psychological Empowerment and Work outcomes will increase (if the Leadership Empowerment increase by one time, the employees' Psychological
Empowerment and Work Outcomes will respectively increase by 0.63 times and 0.53 times). This results have been proven by Raub and Robert [13], Albrecht and Andreetta [3], Humborstad et al. [17], Klerk and Stander [4], Özaralli [5], Chow [19]. And, the Psychological Empowerment factor has a positive impact on the Work Outcomes with a regression coefficient of 0.27 .

This means that, once the Psychological Empowerment factor is better, the Work Outcomes will increase (if the Psychological Empowerment increase by one time, the Work Outcomes will respectively increase by 0.27 times). This results have been proven by Seibert et al. [22], Siachou and Gkorezis [23], Çetin and Askun [24].

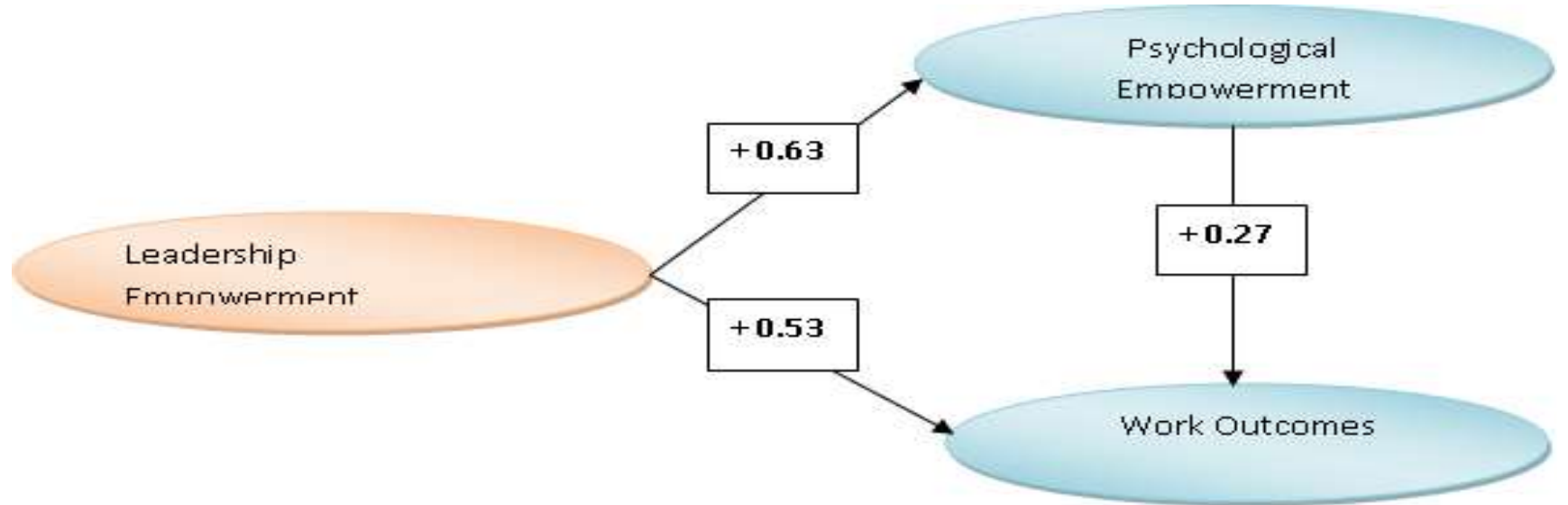

Figure 3: Results of the structural model analysis show the impacts of leadership empowerment on the employees' psychology and work outcomes at financial institutions in Ho Chi Minh City

Source: Author's analytical results. 
Thus, after performing the analysis of the SEM linear structure model, the study has showed the relationship between Leadership Empowerment, Psychological Empowerment and Work Outcomes, among which the Leadership Empowerment has a positive impact on Psychological Empowerment and Work Outcomes; Psychological Empowerment factor has positive impacts on employees' Work Outcomes.

\section{Conclusion and Policy Implications}

Based on the theories related to Leadership Empowerment, Psychological empowerment and Work outcomes, previous studies related to the topic of the research, the author has built a scale and proposed research model with 3 main factors including: (1) Leadership Empowerment, (2) Psychological empowerment and (3) Work Outcomes.

Next, the author conducted qualitative research to correct and supplement errors if any, then conducted a survey and conducted a formal survey to collect the opinions of employee at financial institutions in Ho Chi Minh City. With the collected database, the author conducted SPSS 20, AMOS 20 software for analysis; the study has achieved certain results as follows:

- The study has showed the most basic notions and scales to measure the factors of Leadership Empowerment, Psychological Empowerment and Work Outcomes; previous studies have showed the relationship as well as the impact of Leadership Empowerment on Psychological Empowerment and Work Outcomes as a scientific basis for subsequent studies.

- Next, the study has made preliminary statistics on the surveyed objects such as gender, education level, age and income.

- At the same time, the results of reliability assessment of the scales through Cronbach's alpha analysis technique have showed that with 14 variables (including variables of the factors) that all meet the evaluation requirements, Cronbach's alpha coefficients are greater than 0.8 and the correlation coefficient of the total variables are greater than 0.3 and the results of exploratory factor analysis EFA have showed that all variables belonging to the factors meet the analysis requirements (factor load coefficient values are greater than 0.5 ); with a total of 14 variables and are arranged in 3 groups of factors, which are LP (Leadership Empowerment), PE (Psychological Empowerment) and WO (Work Outcomes).

- In particular, the results of the confirmatory factor analysis CFA have showed that the model is consistent with market data, the scales ensure the reliability and the concepts achieve discriminant value and the SEM linear structure model has showed: (1) Leadership Empowerment has a positive impact on Psychological Empowerment and Work Outcomes of employees; Psychological Empowerment factor has a positive impact on Work Outcomes of employees.

Based on the results from the model, to increase the Work Outcomes of employees at financial institutions in Ho Chi Minh City, the study proposes several administrative implications as follows:

- Financial institutions need to improve the spirit of teamwork and making comments for employees to improve their autonomy and understand the assigned tasks.

- Financial institutions need to regularly organize soft skills training sessions for employees to get all the necessary skills at work to help them proactively propose ideas and solve problems.

- Moreover, financial institutions need to uphold the spirit of self-discipline at work, regularly consult with employees in solving work-related issues of each employee.

- At the same time, financial institutions must clarify the responsibilities and roles of each employee in the work so that they are properly aware of their position in the work.

- Last but not least, leaders at financial institutions can clarify the right of selfdetermination in the work that employees can perform, in order to increase the responsibility and sense of employees with their current work.

In spite of trying to perfect the study in the best way, however, due to time and knowledge limitations, the study still has some certain limitations such as the sample size is still quite small, the scope of research is at financial institutions in Ho Chi Minh City only. Therefore, the subsequent studies can increase the sample size and expand the scope of 
research across many other organizations, fields and provinces [27-29].

\section{References}

1 Spreitzer GM (1995) Psychological empowerment in the workplace: Dimensions, measurement and validation. Academy of Management Journal. 38(5):1442-1465.

2 Albrecht SL, Andreetta M (2011) the influence of empowering leadership, empowerment and engagement on affective commitment and turnover intentions in community health service workers: test of a model. Leadership in Health Services. 24(3):228-237.

3 Klerk DS, Stander MW (2014) Leadership empowerment behavior, work engagement and turnover intention: the role of psychological empowerment. Journal of Positive Management. 3:28-45.

4 Ozaralli N (2015) Linking empowering leader to creativity: the moderating role of psychological (felt) empowerment. ProcediaSocial and Behavioral Sciences.181:366-376.

\section{Amundsen S, Martinsen ØL (2014) Empowering leadership: construct clarification, conceptualization, and validation of a new scale. Leadership Quarterly. 25(3):487-511.}

6 Arnold JA, Arad S, Rhoades JA, Drasgow F (2000) the Empowering Leadership Questionnaire: the Construction and Validation of a new Scale for Measuring Leader Behaviors. Journal of Organizational Behavior. 21(3):249-269.

7 Clark RA, Hartline MD, Jones KC (2009) the effects of leadership style on hotel employees' commitment to service quality. Cornell Hospitality Quarterly.50:209-231.

8 Menon s (2001) Employee Empowerment: an Integrative Psychological Approach. Applied Psychology. 50(1):153-180.

9 Campbell JP (1990) Modeling the performance prediction problem in industrial and organizational psychology, In M. D. Dunnette, \& L. M. Hough (Eds.). Handbook of industrial and organizational psychology (2nd ed. 687-732). Palo Alto, CA: Consulting Psychologists Press.

10 Motowidlo SJ (2003) Job Performance. in W. Borman, D. Ilgen, \& R. Klimoski (eds.). Comprehensive Handbook of Psychology. 12 (39-53). New York, Ny: Wiley.
11 Yilmaz OD (2015) Revisiting the impact of perceived empowerment on job performance: results from front-line employees. Turizam. 19(1):34-46.

12 Raub S, Robert C (2010) Differential effects of empowering leadership on inrole and extra-role employee behaviors: exploring the role of psychological empowerment and power values. Human Relations. 63(11):1743-1770.

13 Park J, Hassan S (2018) does the influence of empowering leadership trickle down? Evidence from law enforcement organizations. Journal of Public Administration Research and Theory. 28(2):212-225.

14 Chen G, Sharma PN, Edinger SK, Shapiro DL, Farh JL (2011) Motivating and demotivating forces in teams: cross-level influences of empowering leadership and relationship conflict. Journal of Applied Psychology. 96(3):541-557.

15 Fong KH, Snape E (2015) Empowering leadership, psychological empowerment and employee outcomes: testing a multilevel mediating model. British Journal of Management. 26(1):126-138.

16 Humborstad SW, Nerstad CGL, Dysvik A (2014) Empowering leadership, employee goal orientations and work performance: a competing hypothesis approach. Personnel Review. 43(2):246-271.

17 Govender K (2017) Empowering leadership and municipal service delivery: a case study of a metropolitan municipality in South Africa. International Journal of Public Administration. 40(5):427-433.

18 Chow IHS (2018) the mechanism underlying the empowering leadershipcreativity relationship. Leadership and Organization Development Journal. 39(2):202-217.

19 Bartram T, Casimir G (2007) the relationship between leadership and follower in-role performance and satisfaction with the leader; the mediating effects of empowerment and trust in the leader. Leadership and Organization Development Journal. 28(1):4-9.

20 Meyerson SL, Kline TJB (2008) Psychological and environmental empowerment: antecedents and consequences. Leadership and 
Organization Development Journal. 29(5):444-460.

21 Seibert SE, Silver SR, Randolph WA (2004) Taking empowerment to the next level: a multiple-level model of empowerment, performance, and satisfaction. Academy of Management Journal. 47(3):332-349.

22 Siachou E, Gkorezis P (2014) Do empowered employees absorb knowledge? An empirical investigation of the effects of psychological empowerment dimensions on absorptive capacity. Management Research Review. 37(2):130-151.

23 Çetin F, Askun D (2018) the effect of occupational self-efficacy on work performance through intrinsic work motivation. Management Research Review. 41(2):186-201.
24 Hoang T, Chu NMN (2008) Textbook of Data Analysis with SPSS Episodes $1 \& 2$. Hong Duc Publishing, TP, HCM.

25 Nguyen DT (2011) Methods of Scientific Research in Business. Social Labor Publishing.

26 Amundsen S, Martinsen ØL (2015) Linking empowering leadership to job satisfaction, work effort, and creativity: the role of self-leadership and psychological empowerment. Journal of Leadership and Organizational Studies. 22(3):304-323.

27 Campbell JP, Mccloy RA, Oppler SH, Sager CE (1993) a Theory of Performance. In N. SCHMITT, \& W. C. Borman (eds.). Personnel Selection in Organizations. (3569). San Francisco, ca: Jossey-Bass.

28 Nguyen DT, Nguyen TMT (2011) Market research syllabus. Labor Publishing. 